\title{
Rechtsgeschichte
}

http://www.rg-rechtsgeschichte.de/rg11

Zitiervorschlag: Rechtsgeschichte Rg 11 (2007)

$\operatorname{Rg} 112007 \quad 66-75$

http://dx.doi.org/10.12946/rg11/066-075

\section{David Daube}

\section{Iauo}

To sleep or not to sleep 


\section{Abstract}

The verb iauo occurs frequently in the Iliad and Odyssey. It is usually translated as »to sleep« or »to spend the night «. Surprisingly, though, iauo as used by Homer also clearly indicates an active behaviour and even the contrary of sleeping. David Daube closely analyses the texts concerned to discover the complete spectrum of the word's meaning to solve the riddle. It is a piece of work very typical of Daube's love of words and hermeneutics. Special thanks go to Calum Carmichael who transcribed the article from the manuscript left by David Daube and gave us the permission to publish it. 


\section{'I $\alpha u ́ \omega$}

To sleep or not to sleep*

In an article »Perchance to dream «I suggest that »to sleep with " in the sense of »to have intercourse with " originated in Egyptian. While never making it in Hebrew, it celebrates its acceptance into Greek in a minstrel's song in the Odyssey where, preceded by the old-established »to mix, " $\mu$ i $\gamma v v \mu \iota,{ }^{\mathbf{I}}$ and $»$ to bed, " $\varepsilon \dot{v} v \alpha$ ó $\alpha,{ }^{2}$ are lined up three different verbs for this metaphor: $\varkappa o \iota \alpha \dot{\alpha} \omega, \varkappa \alpha \tau \alpha \delta \alpha \rho \theta \dot{\alpha} v \omega$ and $\varkappa \alpha \theta \varepsilon v \delta \delta \omega .{ }^{3}$ Four if we accord $\varepsilon \ddot{\delta} \delta \omega$ separate ranking. ${ }^{4}$ Here I raise the question why $i \alpha v \omega$, its principal meaning »to sleep « according to Liddell and Scott, ${ }^{5}$ is missing. One possible answer is that we cannot expect in a romantic ballad a complete listing of synonyms: three are good enough to make the point. Another, on which I shall here concentrate, that $i \alpha v \omega$ never does signify »to sleep « and can signify pretty much the opposite.

As it happens, its debut in Iliad 9.325 is enough to rule out »to sleep. «Achilles reminds his visitors how tirelessly, prior to Agamemnon's overweening behaviour, he had devoted himself

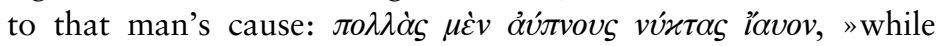
íavov many sleepless nights, " he exclaims, he yet devoted the days to battle. By the nocturnal effect, i $\alpha \dot{w} \omega$ is no doubt meant what receives repeated mention in Book 9: ${ }^{6}$ the thwarting of Trojan attempts to interfere with Greek boats in the dark. At any rate, "while I slept many sleepless nights « would be nonsense. A. T. Murray translates »I was wont to watch. «7 Reasonable, though doing no justice to the complicated vocable. In Odyssey

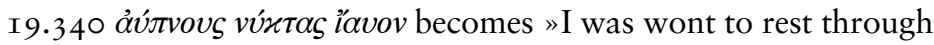
sleepless nights. ${ }^{8}$ No more convincing; see below.

Alas, I cannot think of an English equivalent that would fit on all occasions. » To manoeuvre, « » to wangle, « » to compulsively, doggedly, engage oneself, persist, " and the like will have to do for the moment. It may render my drift clearer, however, if I confess right away to being directed by i $\alpha \dot{v} \omega$ 's onomatopoeia. Not representing any fixed rational concept, its sound indicates an unwavering stick-to-itness under pressure. In fact, two shouts listed by Liddell and Scott independently of it, and indeed, of one another, $i \alpha \tilde{v}$ and iavor, seem to reflect the same background. Both are found in Aristophanes' The Frogs. ${ }^{9}$ The servant of Dionysos, being

* Aus dem Nachlass von David Daube mit freundlicher Genehmigung von Calum Carmichael, der den Text aus dem Manuskript transkribiert hat.
I Odyssey 8.268, $27 \mathrm{I}$.

2 Odyssey 8.292 .

3 Odyssey 8.295, 8.296, 8.3 I3.

4 Odyssey $8.317,337$.

5 A Greek-English lexicon, compiled by Henry GeORge LidDell and Robert SCOTt, Oxford I968, $8 \mathrm{I} 6$. The same meaning is attributed to $\varepsilon^{v} v \alpha v^{\prime} \omega$ and $\pi \alpha \rho \iota \alpha u ́ \omega, 568$, I339. On their accounting for $\ddot{\alpha} \omega$ A II and $\alpha \ddot{v} \omega \mathrm{C}$ as probable pre- cursors of $i \alpha u ́ \omega, 299,285$, see below.

6 Iliad 9.435 f., 650 ff., 672 ff.

7 Homer, The Iliad. With an English translation by A. T. Murray, 2 vols., London, New York I924, vol. I, 405 .

8 Homer, The Odyssey, with an English translation by A. T. MuRRAY, 2 vols., London, New York I9I9, vol. 2, 253.

9 The Frogs 27I, I029. 
recalled to his duty from a short break, "Xanthios, where's Xanthios, is it Xanthios there? " answers $i \alpha \tilde{v}$ : "must needs be here, " "ready for the tussle « (Liddell and Scott: "ho or holla « - not satisfactory). And, on a higher level, Dionysos impressively approves of Aeschylus having the Persians try to conjure their great, dead King Darius back, exclaiming iavor, » may it be contrived « (Liddell and Scott: »exclamation of sorrow « - again, too general). ${ }^{\text {Io }}$ My brother commented on Aeschylus' positive attitude to the Persian monarchy. ${ }^{\text {II }}$

Let us survey the material, including $\dot{\varepsilon} v \iota \alpha \hat{v} \omega$ and $\pi \alpha \rho \iota \alpha \dot{v} \omega$. To Iliad 9.325 I shall come back now and then. 9.336, too, concerns Achilles. Conquering a pro-Trojan city, he slays the head and his three brothers and takes captive his wife Briseis. The two settle down in rare, true love, but Agamemnon compels him to hand her over to him. Henceforth Achilles stays out of the war and when Agamemnon hard pressed, sends a delegation offering magnificent terms, he refuses: the offence - to appropriate his wife ${ }^{\mathrm{I2}}$ - was too bad. It is here that he interjects a grimly ironical congratulation: $\tau \tilde{\eta}$ $\pi \alpha \rho \iota \alpha u \omega v$ $\varepsilon \rho \pi \varepsilon \sigma \sigma \theta \omega$, "with her, keeping at it, let him be joyous. « Really, a curse. That she will never take to Agamemnon is as clear as can be. ${ }^{\mathbf{3}}$ Murray translates "let him lie by her side and take his joy. « ${ }^{\mathbf{I} 4}$ Too simple. Worse: forgiving. Whereas his tremendous rage is confirmed by the lines immediately following. ${ }^{{ }^{5}}$

(A giant appendage to forestall a giant misunderstanding. I am not overlooking his having fair-cheeked captive bed-companion even at this stage. Actually, he also provides Patroclus with one, and when Patroclus is killed, draughts captured Trojan women as mourning choristers. ${ }^{16}$ Nor do I write off his monstrous wish ${ }^{17}$ that Briseis had perished with her family before coming between him and Agamemnon, so he would have been there to rescue Patroclus from the Trojans. I share Murray's verdict in his Introduction to the Iliad that we must not postulate interpolations or diverse sources simply on the ground of change of mood or the like. In the Odyssey, emotional spontaneity is already in retreat, but in the Iliad it is still almost Oriental. ${ }^{18}$ The Briseis just mentioned is an illustration. Not only does Agamemnon swear that he never touched her ${ }^{19}$ but the Iliad ends with her lying down for the night beside Achilles in the innermost part of his hut. ${ }^{20}$ Or look at Book 23, with ups and downs for all, even Achilles, but in 24. I ff. the others remember supper and sleep while he sheds tears for his

IO B. B. Rogers, in the Loeb edition of Aeschylus, London, New York I924, 2, 392, notes the allusion to Aeschylus' The Persians 625-676.

i i Benjamin Daube, Zu den Rechtsproblemen in Aischylos' Agamemnon, Zürich I938, 34 ff.

I2 That is what he calls her: Iliad 9.336.

I3 E. g. Iliad I.348. See also n. 20 on 24.676 and $24.130 \mathrm{f}$.

I4 Op. cit. (nt. 7), 407.
I 5 Iliad 9.34 I ff.

I6 Iliad 9.663 f., I 8.399. Note that the dying Patroclus is taunted by his slayer Hector with having looked forward to carrying off women from conquered Troy, Iliad $16.830 \mathrm{ff}$.

I7 Surfacing only once, at the first meeting with Agamemnon after Patroclus' death, I9.57 ff.

I 8 See my Judas, California Law Review 82 (I994), IOI f [NTJ, 789].
I9 Iliad I9.256 ff. we would know even without this confirmation. 20 Iliad 24.676 , making good the wish of his mother, Iliad 24.I30 f. 
friend. A search for parallels in the Old Testament might set off from David lamenting his slain »brother Jonathon, thy love to me was wonderful, passing the love of women. «"

Phoenix, for his mother's sake, seduced a young beauty his father was in love with. His father cursed him and he resolved to emigrate. His kinsfolk deplored his decision and arranged nightly illuminated festivities in order to prevent an escape in

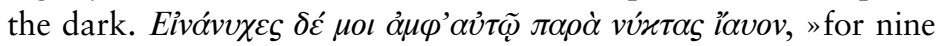
nights around me throughout the nights they manoeuvred « : 9.470. Murray: ${ }^{22}$ »they did watch. « At least radically different from »they did sleep, « but missing the special, twisted character of the activity. It is in fact fairly close to the sense in the first example above, 9.325, where Achilles »operates « in the dark, »doggedly tracing, " »distractingly sticking around, « »interfering with, « the Trojan intruders. The effort of the relatives, however, was in vain: in the tenth night Phoenix found a daring, unorthodox way out.

In a critical phase of the siege of Troy, Hera, favouring the Greeks, resolves to put Zeus, favouring Troy, out of action for a while. Pretending that she plans to restore love between an estranged divine couple, Oceanus and Tethys, she asks Aphrodite - who is on the Trojan side - to fit her out for maximum efficiency. Aphrodite, unaware of the deceit, ${ }^{23}$ agrees to do so for »iavicls in Zeus" arms «: I4.2I3. Definitely not "thou sleepest " as in Murray. ${ }^{24}$ "To sleep with « in the sense of » to have intercourse with, " does not yet figure in the Iliad. It does in the formal, dignified sense of " to share a bed with " for which i $\alpha v^{\omega} \omega$, however, is obviously not an appropriate designation. What she means is that, despite the conflict about the war, the noble enterprise of reconciling Oceanus and Tethys chimes perfectly with Hera's marital role: "you persist in, manage to hold on to, the embrace of noble Zeus." For Aphrodite to undermine this, or even to withhold her support, would be wrong and she lends her the »beguilement that steals the wits even of the wise. ${ }^{25}$

In I 8.259 Polydamus, a Trojan hero, explains that so long as Achilles refused to participate in the war, an experienced fighter like Polydamas could hope for some success by being iav́ $\omega v$, "manoeuvring, " "probing, « among the Greek ships - a chance gone for good now that Patroclus' death at Trojan hands reawakens Achilles' hatred to the full. It is more or less the iav' $\omega$ that we found on the Greek side in the first text above, 9.325:

2I 2 Sam I:36. However, the complications are more demanding than in the Greek field; for a hint see my Sons and Strangers, Institute of Jewish Law I984, $43 \mathrm{f}$. [BLL, I $85 \mathrm{ff}]$.

22 Op. cit. (nt. 7), 4 I 7.

23 Though equally capable of it: Iliad I4.I97 Hera versus Aphrodite, Iliad 3.405 Aphrodite versus Helen.

24 Op. cit. (nt. 7), vol. 2, 83.
25 Iliad I4.2 I7. "Sleep, Lord of all gods and all men, " is indeed also recruited by Hera, but for a different part of her complicated enterprise: Iliad 23 I ff. 
Achilles before his falling-out with Agamemnon, playing the same game protecting the fleet as Polydamas plays in order to get the better of it. And again, the machinations of Phoenix's family are quite comparable. ${ }^{26}$ Murray is completely at a loss: íavov becomes "I spent the night, " remote from its central sonar element. ${ }^{27}$ No doubt the military stroke in question would often be resorted to in the dark - as in 9.325 - but this is by no means essential. We look in vain for an allusion to night both in this episode and in 19.7I to be introduced next; while, indeed, it is noticed more than once - e. g. $9.240 \mathrm{ff}$. - that attacks on a fleet are best carried out in daytime.

I9.7 I depicts an Achilles eager to prove that, once he is back in action, few Trojans will any longer want to $i \alpha u \in \varepsilon v$ » operate, « »stick around, « by the boats. Lucky enough to escape. Murray again has to »spend the night, « missing what holds the various applications of the verse together. ${ }^{28}$

To go on to the Odyssey - the hero, all his comrades having perished in a storm, was stranded at an island belonging to the nymph Calypso. She fell in love with him at sight and took him in. $\mathrm{He}$, however, as the years went by longed to return to his mortal ties. Though night after night, iaúcoxe »he pertinaciously held out, " 5.154 - continues " and perforce in the hollow caves, an unwilling one at the side of a willing one " - he sat in tears all day at the shore looking towards Ithaca. This application of sexual "holding out " is more modern than anything in the Iliad but an approach to it on the female side may be seen in the description of Hera as »persisting in, « »holding on to, « the embrace of Zeus. ${ }^{29}$ Murray, in the place of " he pertinaciously held out, « has " he would sleep by her side. « $^{3 \circ}$ There is no trace of »to sleep « in the original; and "to sleep by her side e eliminates, covers up, the damning message of the original, the laboured nature of his performance.

9.I 84 introduces us to the cave of Polyphemus where many herds of sheep and goats iav́coxov, "were sticking, "for the night, while their owner, says 9.187, غ̇víave, "was sticking, " alone in a mighty hall around it. It is not as if »sleep " were unknown in this world. Polyphemus in the end did fall victim to »sleep the allsubduer, « $\check{\pi} \pi v \varsigma$ $\pi \alpha v \delta \alpha \mu \alpha \dot{\tau} \omega \rho$, after being treated to an exceptionally strong wine by Odysseus. ${ }^{3 \mathrm{I}}$ But this is no reason to substitute the concept here. Not a few animals do spend stretches in the dark in what looks like concentration on a strange purpose; and Poly-

\footnotetext{
26 Iliad 9.470.

27 Op. cit. (nt. 7), vol. 2, 307.

28 Op. cit. (nt. 7), vol. 2, 34I.

29 Iliad I 4.2I3.

30 Homer, The Odyssey, with an

English translation by A. T. Mur-

RAY, 2 vols., London, New York

I9I9, vol. I, 8I.

3I Odyssey $9.203 \mathrm{ff} ., 345 \mathrm{ff}$.; $»$ the all-
subduer « in $372 \mathrm{f}$.
} 
phemus, the most ruthlessly independent of all Cyclopes, would share this feature. Murray translates "were, was, wont to sleep. «32 No serious mistake, but it does substitute the ordinary for the special. Support for this approach will be furnished by I4.I6, I 8 .

Antiope was proud i $\alpha \tilde{v} \sigma \alpha l$, " to have managed, " in great Zeus's arms - with two famous sons resulting: II.26I. The phrasing is as in Iliad I4.2I3, about Hera with Zeus. Murray's »she had slept « once again neglects the special note, the reference to delicate manœuvre. ${ }^{33}$

In Odysseus's absence, his faithful swineherd Eumaeus built an enormous court for hundreds of swine, with beds, however, for the females only: the boars (those left after delivery of a considerable number to Penelope's suitors for their feasts) l'avov outside, I 4.I 6, and, with them, always four dogs íavov, I4.2 I. Murray translates » slept «- quite unacceptable, with nothing to account for the appearance, double appearance, of the rare word. ${ }^{34}$ In reality, the reference is to a very active program, fully spelled out in connection with the dogs: »by them (the boars) ever l' $\alpha v o v$ four dogs, savage as wild beasts, which the swineherd had reared." Anything but "sleep « i $\alpha v o v$ definitely means "manoeuvred, " »lurked. «Indeed, the steady watchfulness almost brought about a catastrophe: in the night of Odysseus's unexpected return after years abroad, the dogs rushed on him and but for Eumaeus's swift intervention, would have inflicted cruel hurt. ${ }^{35} \mathrm{Au}$ fond, the boars and dogs are playing the same role against nocturnal invaders as are, in the Iliad, Achilles against Trojans and Polydamas against Greeks. ${ }^{36}$ The »sticking " of owner and herds in Odyssey 9.I 84, I 87 is not too remote. (We must not expect absolute precision. At the end of Book I4, Emmaeus offers Odysseus - who has not yet revealed his identity - a bed in the building for comfortable sleep while he himself follows his routine, i.e. lies down, well armed, outside where the boars $\varepsilon \tilde{\tilde{v} \delta o v}$, »slept, « yes, »slept«: I4.532.)

I 5.557 tells us how Telemachus, after a lengthy absence, returns at night to the farm with its enormous number of swine, among them हैvíavvv, "was sticking, " the worthy Eumaeus. Murray: »slept. « 37 Well, he did sleep, in a sense, but that is not the point here. The point, after what we have just heard in Book I4, is that there was this inconspicuous guard continuously at work.

By 19.340 Penelope does not yet know that the poor shipwrecked visitor is her husband. But what he has told her made

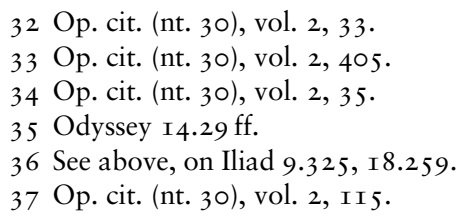


her respectful enough to offer him comfortable bed, cloaks, bath. Which he declines: "I will lie as in time past íavov through sleepless nights. "I I vov surely signifies »I wangled « or the like. Murray renders it »I was wont to rest $"::^{38}$ as if idyllic contentment had been attained. ${ }^{39}$

In 22.464 Telemachus, furious with the egoistic women captives who exploited his family's situation and "lavov with the wooers of Penelope, subjects them to a more cruel death than had been planned by his father. ${ }^{40}$ Murray: "were wont to lie. ${ }^{4 \mathrm{I}}$ They were that but what is brought out here is an ugly aspect: "were keeping at it, « »operating. "Worth recalling, despite enormous differences in detail, are Iliad 9.336, I4.213, Odyssey 5.I 54, I I.26I.

This concludes the list, but an extra few lines may be devoted to the two composites. As for $i \alpha v \omega$ lined with $\pi \alpha \rho \alpha$-, it seems to indicate a special "sticking to without any let-up. «In Iliad 9.336 the paradoxical effort of Agamemnon with Briseis. In 9.470 the extraordinary nocturnal supervision of Phoenix. In Odyssey I4.2 I, actually the role of watch-dogs (while a simple iav $\omega$ is enough for the boars, I4.I6). In 22.464 the outrageous line taken by those inmates of Odysseus's harem who reveled in gratifying the wooers: enjoying, according to $20.6 \mathrm{f}$., both the act and the ensuing merriment among themselves. 'Eviav́ Polyphemus is introduced, 9.I87: "Inside (the hall) Evvíave, was sticking, a monstrous man. «Emphasizing his utter, negative isolation. And utter isolation in a very different, positive spirit is the

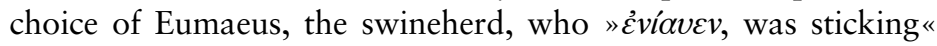
faithfully among his master's animals at night, I 5.557 (The contrast is so impressive, almost proves the same mind at work in the two lines.)

A glance at $\ddot{\alpha} \omega$ may be of interest. For Liddell and Scott,

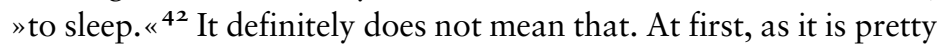
close to $i \alpha v \omega$, I thought it might be an earlier form of it - earlier because shorter. But then I found it really covers a wider range, so probably came into use when the magic of the latter was somewhat deflated. Two considerations support this secondary dating: the sound is less effective, and all four occurrences are in the Odyssey.

3.I 5 I. ${ }^{43}$ No sooner had Troy fallen than an evening assembly of the victors split sharply, one camp led by Menelaus favouring immediate return, the other by Agamemnon against. That night so years later Nestor tells Telemachus who is visiting to find out

38 Op. cit. (nt. 30), vol. 2, 253.

39 I shall return to it when considering $\not \alpha \omega$ in 342 .

40 Odyssey 22.443 ff.

4I Op. cit. (nt. 30), vol. 2, 37I.

42285.

43 Op. cit. (nt. 30), vol. I, 79. 
about his father - $\dot{\alpha} \dot{\varepsilon} \sigma \alpha \mu \varepsilon v$, »we held on. « Not as Murray humanely renders » we rested, « but » we held on, « »stuck to it «: darkness and excessive drink ruled out immediate action, yet the very next words are "pondering mischief in our minds against one another, « with, indeed, a vengeful anti-Greek Zeus in the background. Not a picture of rest; and, as soon as morning dawned, the Menelaites - Nestor among them - did sail off. ${ }^{44}$

$3.490=$ I 5. I 88.45 When Telemachus undertook his expedition to find out about his father's fate, the overland portion of his journey had to be pressed into two days each way. ${ }^{46}$ Both on the way there and back he and a son of Nestor's drove the first day till darkness was impenetrable to the home of the superb Diocles of Pherae. There, we are told concisely, $\ddot{\alpha} \varepsilon \sigma \alpha v$ the night and were given to eat. Murray's »they spent" the night is not adequate. Should be "they held out, " »bore with «: at the earliest sign of dawn, the report goes on, they continued at full speed. The contrast with the entertainments offered by Nestor and Menelaus is staggering. What was expected from Diocles was not sumptuousness and celebration but effective minimum support. So extraordinary - in the whole Odyssey we hear nothing else about him, yet this feat of understanding is fully recorded, nine lines word for word, both on the way out and on the way back. The verb is pretty close to its sense in 3.I $5 \mathrm{I}$, an enforced delay of those siding with Menelaus, and not too far from, say, 5.I 54 , Odysseus "holding out the night « with Calypso, pressured against his principal inclination homewards. ${ }^{47}$

I $6.367 . .^{8}$ Antinous, ambitious, unscrupulous, hearing of Telemachus's visit abroad, takes command of a boat with twenty volunteers, in order to sink him as he approaches his country on return. However, owing to some oddities in Telemachus's travel arrangements they miss him; and they do so although they are untiringly watchful by day and even when the sun set - so Antinous reports - we never » $\ddot{\alpha} \sigma \alpha \mu \varepsilon v$ a night " - Murray » spent a night « - on land. Even here, "to spend, " though tolerable, misses a point. Should be "to wangle, « »misuse « or the like. Any ordinary troop would relax at night because the likelihood of the enemy passing through is considerably diminished. Not them: in their eyes it would have been a contemptible submission. ${ }^{49}$

I9.342..$^{\circ}$ Two lines before, we just saw, Odysseus declines some comforts offered by Penelope, who does not yet know -

44 Just as in Odyssey 4.843 Penelope's wooers, wanting a free hand, "pondered murder in their minds against Telemachus « and recklessly took whatever steps suited the moment.

45 Op. cit. (nt. 30), vol. I, I05, vol. 2 , 87.

46 Why, it would be too long to explain.

47 See also on Odyssey I9.340 ff.

48 Op. cit. (nt. 30), vol. 2, I43.
49 The generally far superior comfort of a night indoors to one on board is vividly brought out in $3.346 \mathrm{ff}$. 50 Op. cit. (nt. 30), vol. 2, 253. 
whatever her hazy premonitions - that it is him. His explanation: he must still "wangle, «iav́ $\omega$, through sleepless nights in a modest place: not yet demobilize, that is. ${ }^{5 \mathrm{I}}$ To this he adds in $34 \mathrm{I} \mathrm{f} .:$ » For many nights $\tilde{\alpha}^{\prime} \varepsilon \sigma \alpha$ upon a foul bed and waited for the brightthroned Dawn. « Clearly, an extra reference to the most recent, near-endless trial period of »holding out, « »enforced role-playing, " night after night, giving in to Calypso's passion, with fortunately, relief during the day. " $A \omega$ here is very close to $i \alpha v \omega$. Murray has »I have lain, « making it pretty much a repetition of what we have already heard in 340; whereas it singles out, bewails, the enforced serfdom to love. Once we grasp this meaning, the term "foul « also, though tolerable, proves a second-best rendering of

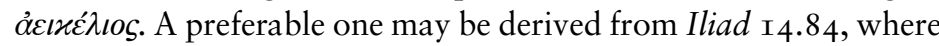
Agamemnon temporarily loses all hope of winning the war and suggests flight, to be advised by a furious Odysseus to take over some other, $\dot{\alpha} \varepsilon ı \dot{\varepsilon} \lambda l o s$, »inglorious, " army. ${ }^{52}$ Surely, just what he might choose as an attribute of his nightly sessions with Calypso.

Towards the end of May, with this paper practically finished, ${ }^{53}$ I came across in the San Francisco Chronicle Commuter Crossword Puzzle the clue »sloth, « indicating a word of four letters. The solution: unau, the two-toed sloth of Brazilian origin, traceable in English from the I7th century. The three-toed one is called ai. Despite all differences, the fundamental onomatopoeia behind these strange nocturnal creatures is remarkably like that behind $i \alpha v^{\prime} \omega$ and $\ddot{\alpha} \omega$. Due not to influence but to profound natural affinity.

The post-Homeric development is quite conservative. Here are three passages from the Homeric Hymns. In To Demeter, the goddess, not revealing her divinity, is engaged by Metaneira to look after her baby son Demophon. She takes to him greatly and decides to render him immortal by anointing him and breathing on him instead of feeding him and suckling him. A third deviation from the ordinary she prudently resorts to at night, a hiding of him in fire. However, it is noticed by his spying mother who implores him not to go along with it. This so upsets Demeter that she gives him up. He will not now be immortal, she explains to Metaneira, though ever remain honoured because »he mounted on my knees and $l^{\prime} \alpha v \varepsilon v$ in my arms. « ${ }^{54}$ The common rendering "and slept « is a distorting simplification. ${ }^{55}$ Far from sleeping, »he held on, « »persisted." Something of this nature figures in a variety of texts: woman does it with man (Hera and Antiope with Zeus), ${ }^{56}$ man

5I Cp. Odyssey 20.I ff., I4I ff., etc. 52 Op. cit. (nt. 30), 78 .

53 [In almost unintelligible handwriting, Daube added a comment that he thought it was finished, but even if it were not, it would have been because of the "acceleration of senility. "It was indeed the last time he worked on any matter because he was soon to move away from his cramped office in the Law School at Berkeley, never again to apply himself to any academic pursuit.] C. C. $54263 \mathrm{f}$.

55 E. g. Hugh G. Evelyn-White, Hesiod, the Homeric Hymns and Homerica, London, New York 1936, 307, 309 .

56 Iliad I4.213, Odyssey II.26I. 
57 Odyssey I4.I6, 2 I.

58 Odyssey I $9.340,342$.

59 Odyssey I4.I6, 2 I.

60289.

6I 290. Here are a few of the relevant texts: the very opening one, above, at nt. 36, Iliad 9.325, refers to a

with woman (Odysseus with Calypso), ${ }^{57}$ at times perhaps more in intent than execution (Odysseus with Penelope) $)^{5^{8}}$ - and there are basically similar instances in the animal world such as the »lurking " of boars and dogs at night. ${ }^{59}$

To Hermes ends with the late-comer among gods and Apollo becoming friends. But to begin with, Apollo criticizes his posing as a kid in a cradle while really engaged in the most far-flung fraudulent tricks. He had better act in a manner, he warns him,

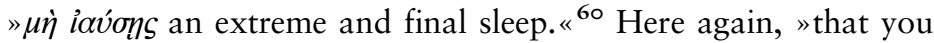
might not sleep an extreme and final sleep « is just not up to the Greek. »That you will not manoeuvre, pretend an extreme and final sleep " or the like is what he demands: followed up by "get out of your cot, « his instrument of such make-believe. ${ }^{61}$ The Loeb translator translates $\dot{\alpha} \lambda \lambda^{\prime} \not \dot{\alpha} \gamma \varepsilon$, "but act, ${ }^{62}$ as an independent introduction, "come now, " and conjures up an »if " to head what follows: »if you would not sleep your last and latest sleep, « do soand-so. Untenable, but hardly avoidable with i $\alpha \dot{\omega} \omega$ demoted.

To Aphrodite's use of the term is no less subtle. ${ }^{63}$ Aphrodite gains enormous standing by arranging liaisons of gods with mortal women and of goddesses with mortal men while herself being intimate with equals only. Zeus, disliking her snobbishness, ${ }^{\mathbf{6}}$ kindles in her a blind passion for a young worthy, Anchises, who shares a tent on mount Ida with other males his age sent up by their families to look after pasturing cattle. So she puts on seductive thisworldly attire and indeed normal height when in reality her head reaches above the roofs. She finds him all alone, playing the lyre, having let his fellow-guardians take out the flocks to feed without him. In response to his admiring welcome she assures him that she is not that special and that, in fact, a fruitful marriage to him has been predicted to her. He, though sensing an unreachable element - »not properly knowing ${ }^{65}$ - enthusiastically complies and they have a long day of intercourse. ${ }^{66}$ By the end of it she is pregnant with a son but her Zeus-engineered infatuation with the father is gone. Indeed, the name she will bestow on the son, Aeneas, means "dread grief ${ }^{6}{ }^{6}$ - evoked in her by him for ever on account of her unworthy bedding, »utterly misled, « ${ }^{68} »$ led astray out of her mind. " ${ }^{69}$ Yet she does her best by him in the circumstances as a mother, has him looked after by nymphs one of whom she will get rumor to credit with his birth ${ }^{70}$ - though only too aware that her part will be guessed by many. Still, when she presents him, about

compulsive going in for the opposite, sleeplessness; Iliad 9.420 has Phoenix's kinsfolk manoeuvre around him for nine nights; in Odyssey 5.I 54 the hero bravely holds out night after night with Calypso.

62 Evelyn-White, 385.

$6349 \mathrm{ff}$.

64 He never shared it but, then, he never risked pregnancy by his liberalism.

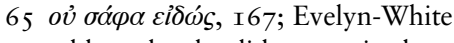
adds "what he did " - not in the Greek.

66 Day, not night, but I shall not expand.

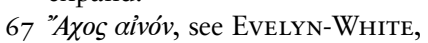
4I9 n. II.

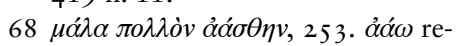
presents an onomatopoeia not too distant from i $i v v^{\prime}$.

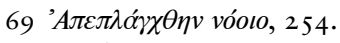
$70284 \mathrm{f}$. 
five years old, to Anchises, he is "quite godlike. ${ }{ }^{7 \mathrm{I}}$ Not surprisingly, Anchises creates a special problem as Zeus-managed intercourse is over and she, come to her senses, aghast at her monstrous lapse. He is guilty of no wrong - so far at least and she does her best to keep it at that. Right away, she sends him into an agreeable sleep allowing her to reassume her veritable Olympian appearance. Once in this state of overwhelming majesty, »she awakened him from sleep ... Arise ... how what unawaking sleep $i \alpha u \varepsilon \iota \zeta,{ }^{72}$ are you clinging to? And consider whether I do look to you to be identical with her as whom you perceived me first with your eyes. «73 To which he responds immediately in the worthiest fashion asking - in vain - to be lifted to her superior world. Evelyn-White misses the essence. Here are four excerpts showing him lost. (I) »She aroused him from sleep ... why sleep you so heavily? « Does away

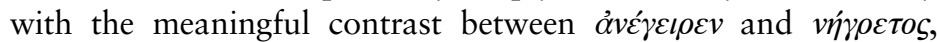
»she awakened " him and his "unawaking " state. (2) »Up ... and consider whether I look as I did. «While he puts » up, « the original has an imperative, ö $о \sigma \varepsilon o$, "arise, « the form resorted to again in the

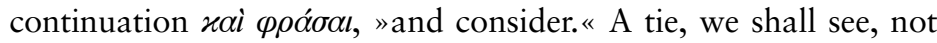
to be neglected. (3) In the main question, "why sleep you « does

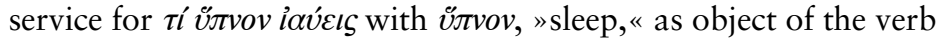
iavisıs; in effect, he brushes aside the latter. (4) A similar sign that he finds the text riddling: he simply suppresses the word $v v$, "now. « So what are we to make of the counsel? There are three parts. (I) »Arise, « a general summons to action. (2) Here follows a pause in the directive, a reflection on the futility of his contented sleep now that she turns out not to participate at all. ${ }^{74}$ (3) Continuation of (I), spelling out the enormous concession demanded: he must give up on her who is just not the one she seemed to be, posed as, at the initial encounter. Indeed, the moment he comes to, sees her as she is, we learn, "he was afraid and turned his eyes aside, hiding his comely face with his cloak. «75

\section{David Daube}

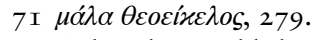

72 At last the vocable here of interest.

$73 \mathrm{I} 76 \mathrm{ff} . \dot{\varepsilon}^{\prime} \xi$ uัлvov $\tau^{\prime} \dot{\alpha} v \varepsilon \dot{\gamma} \gamma \varepsilon \iota \rho \varepsilon$...

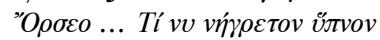

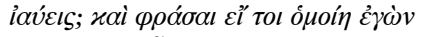

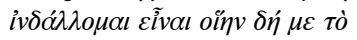

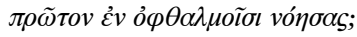

74 To simply disregard ny may be going too far even when its role is less weighty. For example, Murray leaves it untranslated in Odyssey 5.299 and 465 : »ah, woe ... what is to befall me - will happen to me - at the last? « instead of "ah, woe ... what now is to befall me" etc.

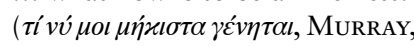
vol. I, I9I, 203). In both cases, making a general plaint - things look grim - from one concentrating on a particularly frightening element of the situation: Zeus's intervention in the first case, frost and wild beasts in the second.
"Now « meaning something like "in view of the present situation." 75 I $82 \mathrm{ff}$. 